AGH DRILLING, OIL, GAS • Vol. 33 • No. $1 \cdot 2016$

http://dx.doi.org/10.7494/drill.2016.33.1.49

\author{
Klaudia Metelska*, Tomasz Cieślik*
}

\title{
A REVIEW OF CURRENTLY AVAILABLE LNG FACILITIES AND MEANS OF TRANSPORT USED FOR SUPPLYING TERMINALS IN NATURAL GAS WITH A PROJECTION OF LNG PRICES IN THE USA
}

\section{INTRODUCTION}

One of the alternative options of diversifying natural gas supply in Poland is shipping liquefied natural gas (LNG) by sea routes from other countries, mostly located in the Persian Gulf, and subsequently regasifying LNG to supply the domestic gas network [1]. The increase of LNG's importance in recent years is associated with a general increase of demand for natural gas. The history of LNG production dates back to the beginnings of the 20th century while its first commercial use took place in 1941. LNG started to gain in popularity with the launching of first commercial deliveries by sea. That happened in 1964 when a transport route from Algeria to the United Kingdom was opened. Another big step in the popularisation of LNG was the Asian boom in the natural gas power station sector, particularly in South Korea and Japan. The annual world consumption of LNG exceeds 330 bn cubic metres, whereas the consumption of LPG amounts to less than $1 \%$ of that volume, CNG being the least popular form [2]. At the moment, Poland consumes about $40 \mathrm{mln}$ cubic metres of LNG. After opening the terminal in Świnoujście, this volume will reach 1.5 bn cubic metres. Currently, the transport sector is dependent almost entirely on oil, which presents a serious ecological and economic threat [1]. The competitive price of LNG in comparison to pipeline conveyed gas and the development of LNG carrier fleets are factors that stimulate LNG transportation. Main producers and exporters are found in the countries of the Middle East, Australia and North America (Fig. 2), thus it is difficult to connect them to the recipients of this fuel - Europe, South Korea and Japan (Fig. 15) The natural gas

* AGH University of Science and Technology, Faculty of Drilling, Oil and Gas, Krakow, Poland 
liquefaction process, achieved by cooling natural gas to minus $160^{\circ} \mathrm{C}$, results in a 600 -fold volume decrease. Subsequently, after regasification due to heating, 100 cubic metres of LNG is transformed into as much as 60000 cubic metres of pure natural gas. LNG is delivered from many suppliers located in various parts of the world, which allows for optimisation of purchase and transport costs. Moreover, it has very precious ecological properties. In its liquefied form, natural gas is neither explosive, toxic nor corrosive. It is a colourless, odourless liquid, stored and transported in very low temperatures under atmospheric pressure or under a light pressure of 2-3 bars in special cryogenic containers. Compared to other hydrocarbons, combusted natural gas emits much less pollution to the atmosphere, mostly carbon. Furthermore, in case of leakage it does not cause contamination of seawater or soil. Thanks to its properties it is an alternative to other fuels, therefore it has a wide range of applications [1]. The increase of LNG deliveries to Japan, where shutting down nuclear plants after the Fukushima accident drove up prices of this resource, is a good example (Fig. 1). As a consequence of an EU directive, LNG could become the most widely used fuel for ships operating on the seas of Europe in the near future. Ships operating on the North and Baltic Sea will have to replace oil with natural gas. In countries such as Germany, the Netherlands and the United Kingdom LNG has shown to be an ideal fuel for short-term consumption during the winter peak period of demand for energy and heating. More and more often it is not only a backup fuel, but a primary one as far as off-grid customers are concerned [2].

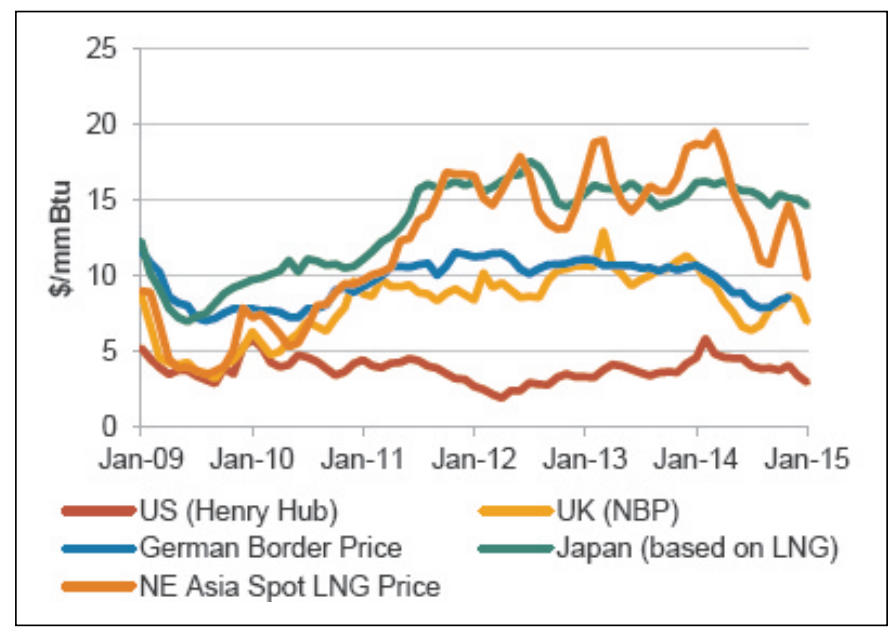

Fig. 1. LNG price changes on the American, British and Japanese market [4]

\section{GAS LIQUEFACTION PLANTS}

In 2015 there were around 82 operating natural gas liquefaction plants with a total capacity of 342 MTA (milion tons per annum). In 2019 the total capacity is planned to 
reach 429 MTA. With an annual production of 77 MTA, Qatar leads the way among LNG producers. Australia ranks second with 63 MTA, followed by Indonesia at 36 MTA. It should be noted that due to numerous LNG plant development projects, Australia will become the world leader in 2019 with a production capacity of 98 MTA (Fig. 2). Almost 200 MTA is produced in facilities built less than 10 years ago and only 4.7 MTA in facilities older than 40 years (Fig. 3). Within the range of preferred capacity, facilities with a yearly production between 4 and 6 MTA are the majority with a 39\% participation on the market. Liquefaction comprises 30-40\% of LNG price. APC3MR (designed by Air Products) occupies a dominating position in the group of preferred liquefaction technologies and as much as $69 \%$ of LNG is produced with this method (Fig. 4) [4-6].

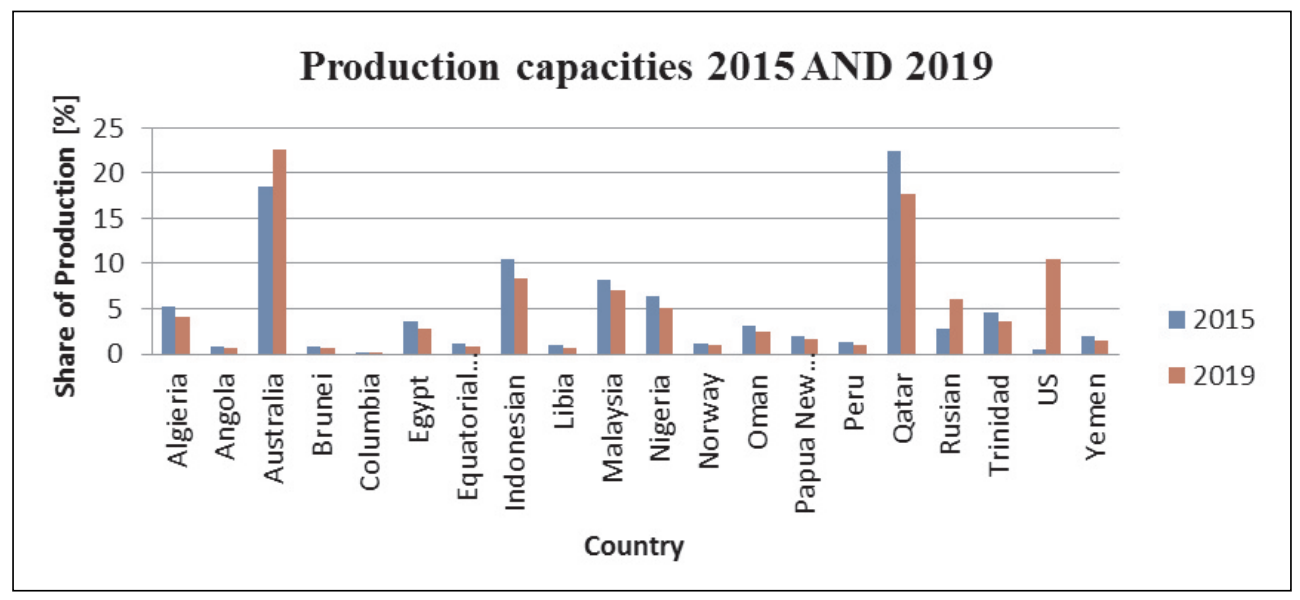

Fig. 2. Percentage share of production for selected countries in 2015 and 2019 (own research on the basis of [4])

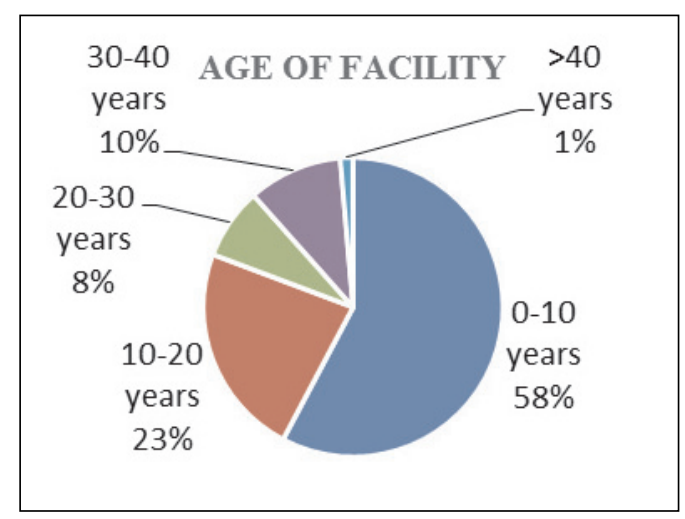

Fig. 3. Share of production in relation to age of LNG facilities (own research on the basis of [4]) 


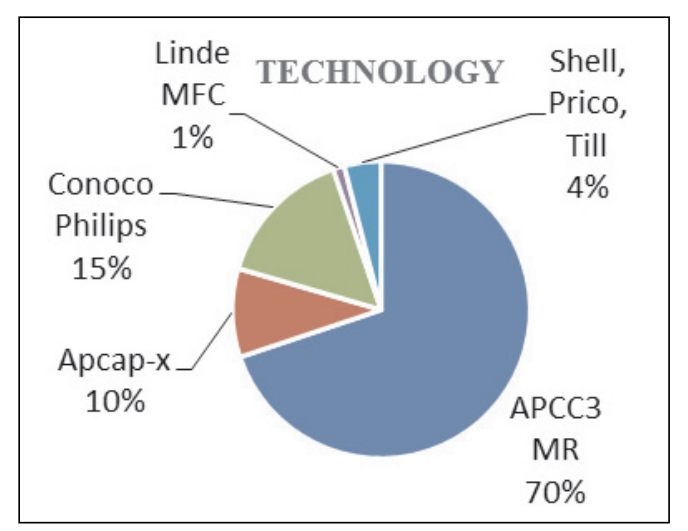

Fig. 4. Participation of particular technologies in LNG production (own research on the basis of [4])

\subsection{Gas liquefaction technologies}

Liquefaction is a process which directly follows natural gas field production and treatment. Liquefied natural gas has the temperature of $-162^{\circ} \mathrm{C}$. LNG does not contain $\mathrm{CO}_{2}$ and in comparison to natural gas has trace amounts of nitrogen (Tab. 1).

Table 1

Natural gas and LNG composition [7]

\begin{tabular}{|l|c|c|c|}
\hline \multicolumn{1}{|c|}{ Constituent } & Pipeline Natural Gas [\%] & Liquefied Natural Gas [\%] & 99\% LNG \\
\hline Methane & 88.9 & 94.7 & 99 \\
\hline Ethane & 5.34 & 4.8 & 1 \\
\hline Propane & 0.46 & 0.4 & - \\
\hline Butane & 0.05 & 0.06 & - \\
\hline Pentane & 0.03 & 0.01 & - \\
\hline Hexane & 0.02 & 0.01 & - \\
\hline Helium & 0.2 & - & - \\
\hline Nitrogen & 5.5 & 0.02 & - \\
\hline Carbon Dioxide & 0.5 & - & \\
\hline
\end{tabular}

During the liquefaction process a compressor is used to reduce the volume of the refrigerant, which causes an increase of is temperature. Afterwards the refrigerant is cooled in a heat exchanger (condenser) and expanded (does work) in the expansion valve. The cold refrigerant takes away heat from natural gas through the exchanger (evaporator) (Fig. 5)[6]. 


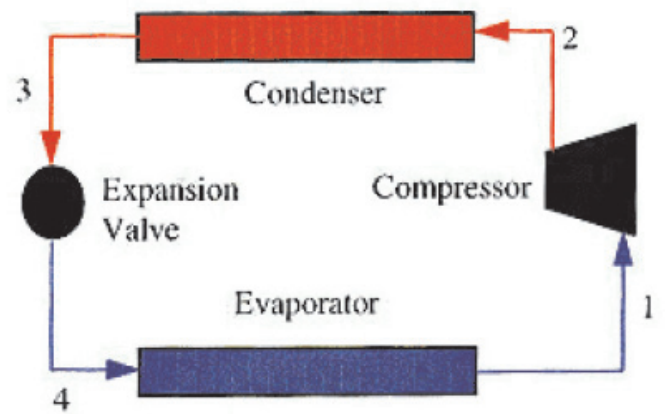

Fig. 5. Diagram of the liquefaction process [6]

\section{APC3MR technology}

Natural gas passes a series of multistage heat exchangers. The heat exchangers contain a chiller, e.g. propane. The chiller is compressed with a turbine compressor, then cooled. After cooling, the compressed chiller is expanded in the expansion valve in order to obtain a low temperature required for pre-cooling of natural gas. After passing cascade heat exchangers, the process gas should have a temperature of $-35^{\circ} \mathrm{C}$. Using a pure component refrigerant for pre-cooling allows for an efficient process characterised by ease of operation. Using a single exchanger reduces the number of devices operating at the same time, yet it also causes a drop in efficiency (Fig. 6).

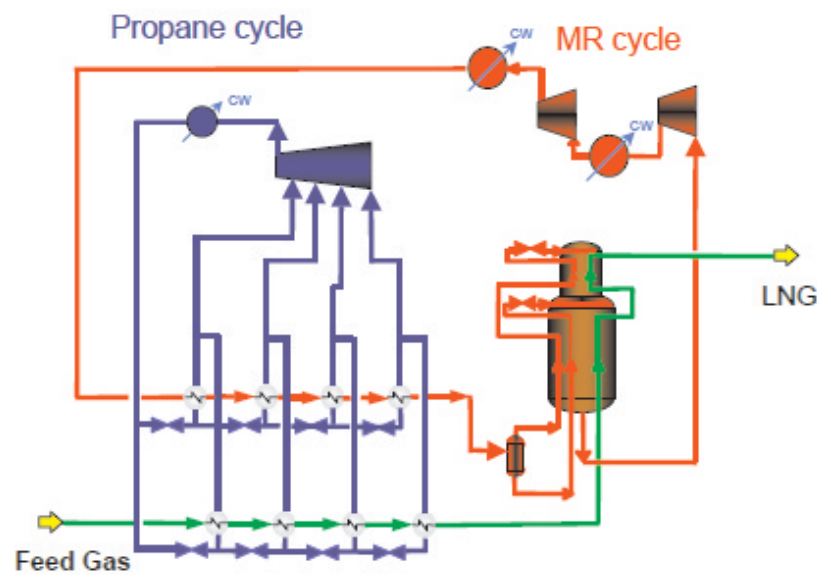

Fig. 6. Diagram of the APCC3MR technology [10]

The next stage is cooling to $-162^{\circ} \mathrm{C}$. At this point, mixed refrigerant consisting mainly of ethane and propane are used. The refrigerant passes through a shared inlet heat exchanger, which allows for increased effectiveness of the process. Subsequently, refrigerant flows to the phase separator where vapour is directed to the main heat 
exchanger and at the same time fulfils the role of a thermal screen, while liquid is cooling natural gas. The technology described above is used in facilities with a capacity of over 1 MTA [6, 8-14].

\section{Conoco Philips technology}

This process is more complicated in comparison to APCC3MR. It consists of cooling natural gas in three equal cycles (Fig. 7). In each of the three cycles, compressors are working with the same power. Each level may be autonomous and in case of emergency of one stage, refrigerant from further stages is not being lost. The following are used as refrigerants: propane for the first and ethane for the second stage, while methane or other substances such as hydrogen fluoride compounds, noble gases or carbon and fluoride compounds are used for the third stage [6, 9, 10, 15-16].

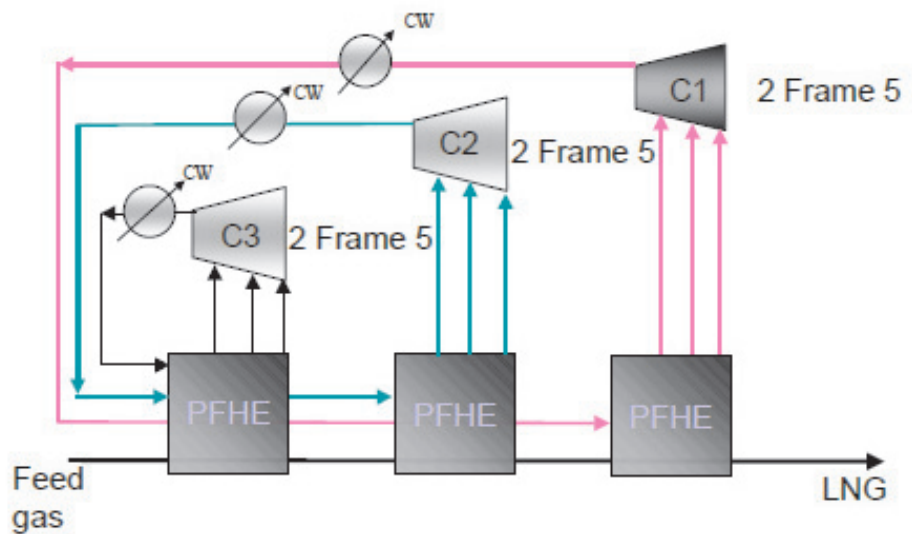

Fig. 7. Diagram of the Conoco Philips technology [10]

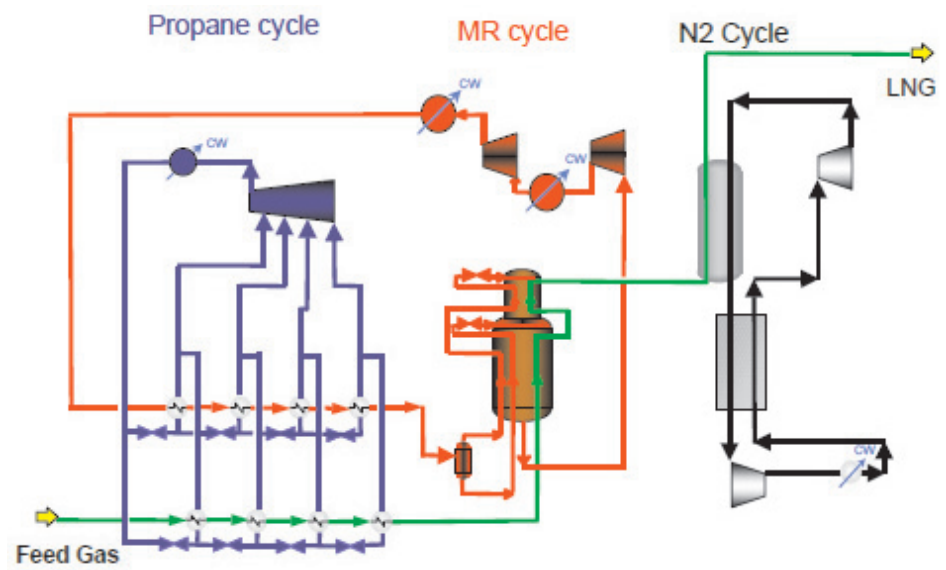

Fig. 8. APX technology diagram [10] 


\section{APX process}

The APX process is a modified APC3MR process (Fig. 8). It is characterized by the fact that pre-cooling is followed by nitrogen sub-cooling. The nitrogen sub-cooling takes place in an additional module equipped with liquid nitrogen and a turbine. The primary advantage that can be distinguished in this process is high efficiency (even up to 8 MTA). The greatest disadvantage of the process is high machinery cost $[6,10]$.

\section{LNG TRANSPORT}

LNG is transferred mainly by means of maritime transport, with the help of ships adapted specifically for that purpose (Fig. 9). The longer the distance to be covered, the more economical it is to use maritime transport due to pipelines' high construction costs (Fig. 10). The shortest voyage length is found between Spain and Algeria (half a day), whereas the connection between Japan and Trinidad is the longest one (30 days). The number of LNG carriers currently used is 411 . The ships' total capacity is $56,846,000$ CBM (cubic metre). The country with the greatest total fleet capacity is Liberia. Its total fleet capacity is 6,935,000 CBM. Japan and Marshall Islands both occupy the second position with a total fleet capacity of 6,500,000 CBM (Fig. 11). 33,848,000 CBM is transported by carriers whose age does not exceed 10 years from launching and only 994,000 CBM by ships over 40 years from launching (Fig. 12). The preferred carrier capacity ranges between 100,000 CBM and 150,000 CBM. The cost of the transport amounts to $10-30 \%$ of the final LNG price. The ship-building technologies that are most frequently used for LNG carriers are moss and membrane technologies (Fig. 13) [4-5, 17-20].

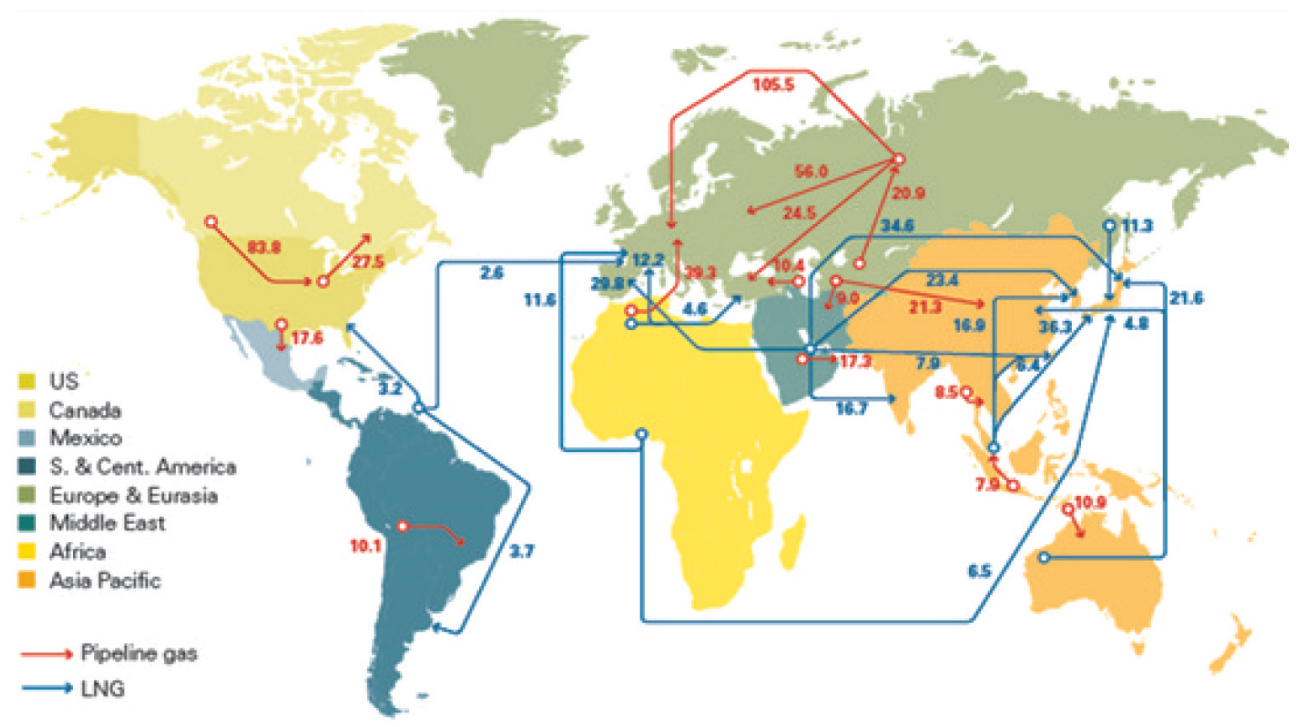

Fig. 9. LNG Transport routes [19] 


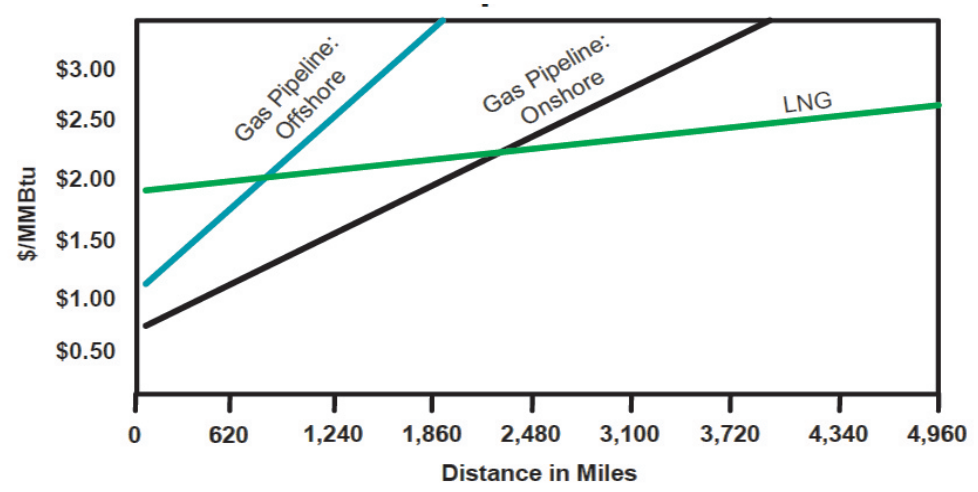

Fig. 10. Comparison of transport costs for natural gas and LNG [20]

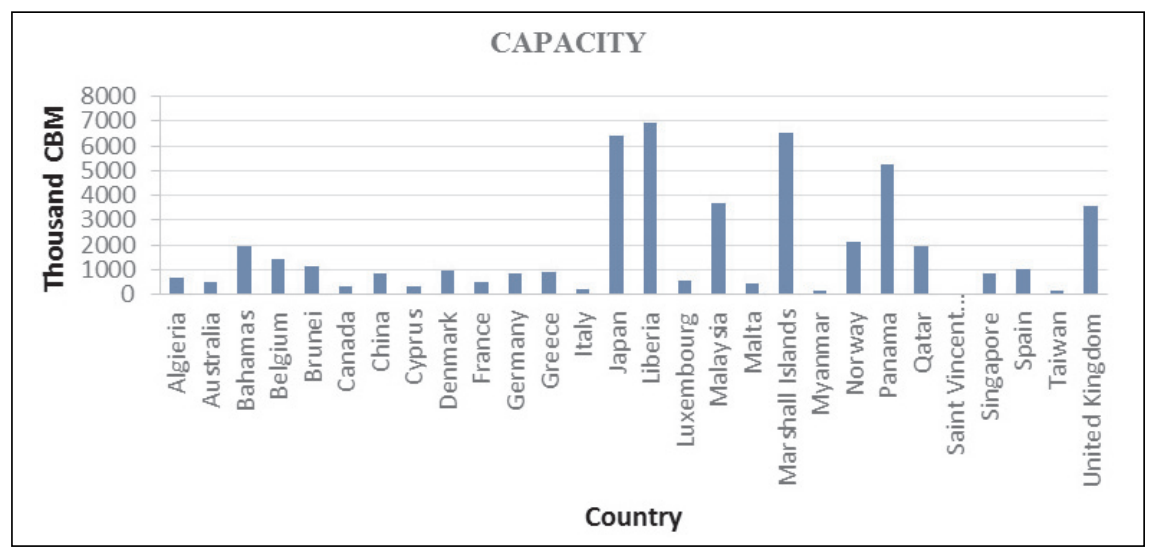

Fig. 11. Total fleet capacity with respect to specific countries (own research on the basis of [17])

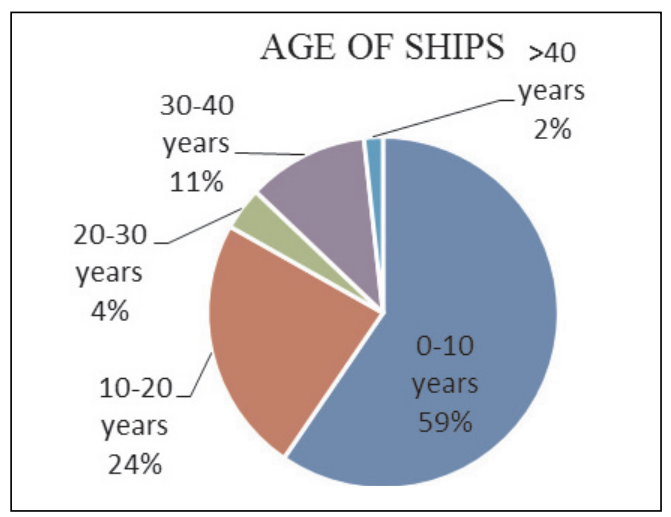

Fig. 12. Ships' age in relation to their share of the world's LNG total transport (own research on the basis of [17]) 


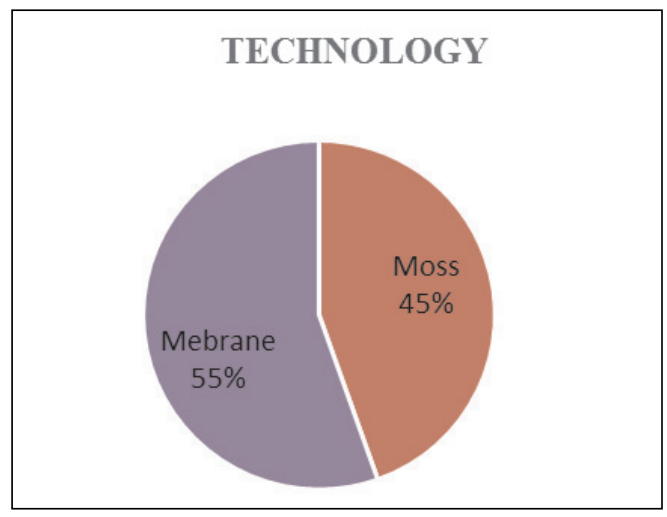

Fig. 13. Type of technology in carriers (own research on the basis of [17])

\subsection{LNG carriers}

LNG is transported by ships which were built in accordance with either moss or membrane technology using special insulation materials (Fig. 14). Vapours can be either liquefied by condensers installed onboard or used to power ship engines. There have now been attempts to replace diesel fuel with LNG on ships. Storage tanks are insulated from other areas of the carrier by walls as much as six feet thick. Shipbuilding companies are now making efforts to increase ships' transport capacities, while at the same time reducing overall mass and costs of production [21-26].

a)

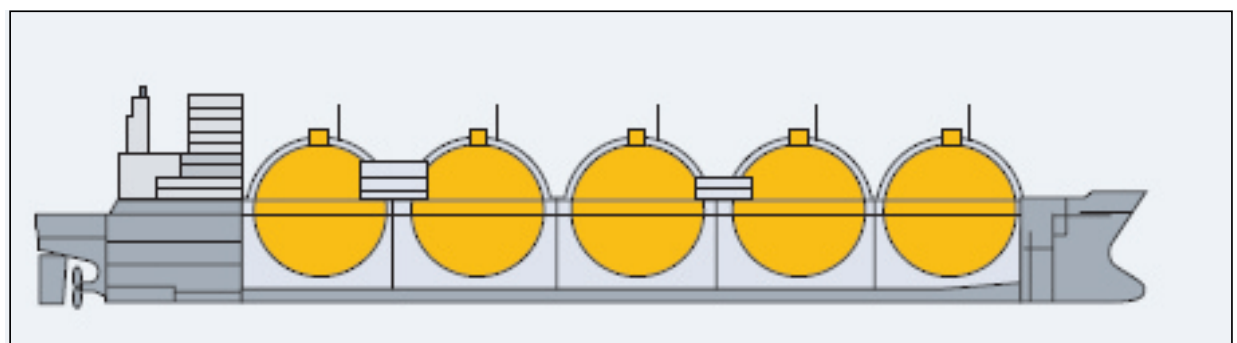

b)

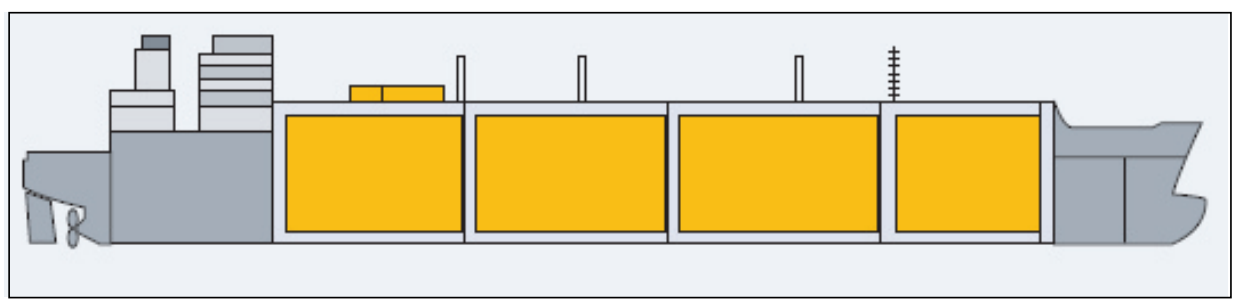

Fig. 14. Moss (a) and membrane (b) vessel types [27] 


\section{TERMINALS}

In 2015 the number of operating LNG terminals around the world was 121 with a total capacity of 761 MPTA. It is estimated that this capacity will be increased to 781 MPTA by 2019. Japan, whose capacity is 190 MPTA, is the leader among LNG consumers (Fig. 15). It should be noted that some countries, for example the USA and Brazil, produce LNG, but also have their own terminals (Fig. 16). Nearly 250 MPTA is being stored in facilities whose age does not exceed 10 years, while 132 MPTA is being stored in facilities which are older than 40 years (Fig. 17). The preferred capacity among storage facilities ranges between 10 and 20 MPTA. Storage costs amount to $15-25 \%$ of the final LNG price. Among the preferred gas storage technologies, onshore technology has a leading position - as much as $93 \%$ of the world's LNG is being stored with the help of this technology (Fig. 18) [4-5].

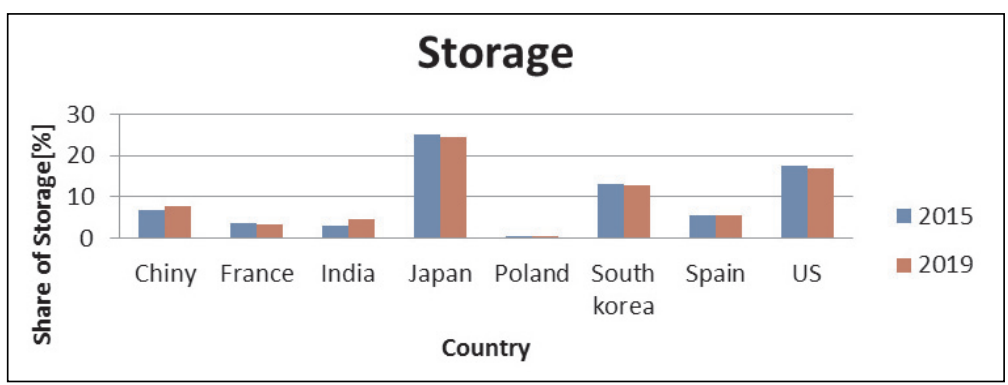

Fig. 15. Number of storage facilities for particular countries as a percentage share of the world total in 2015 and 2019 (own research on the basis of [4])

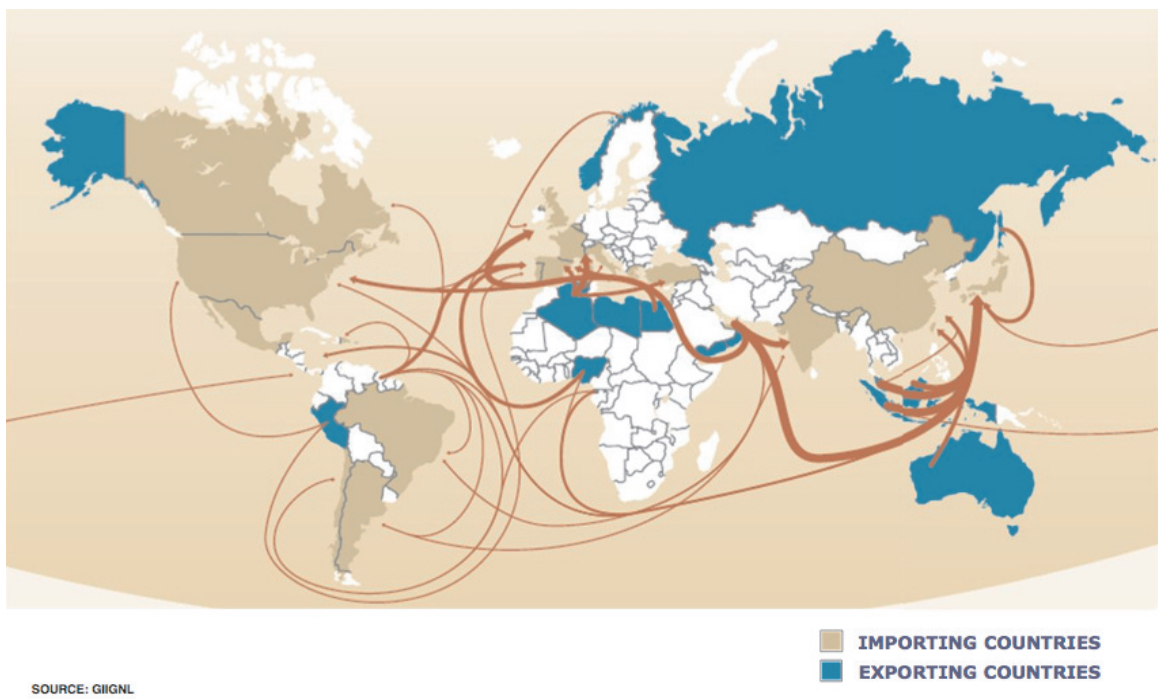

Fig. 16. Map of countries which import and export LNG [33] 


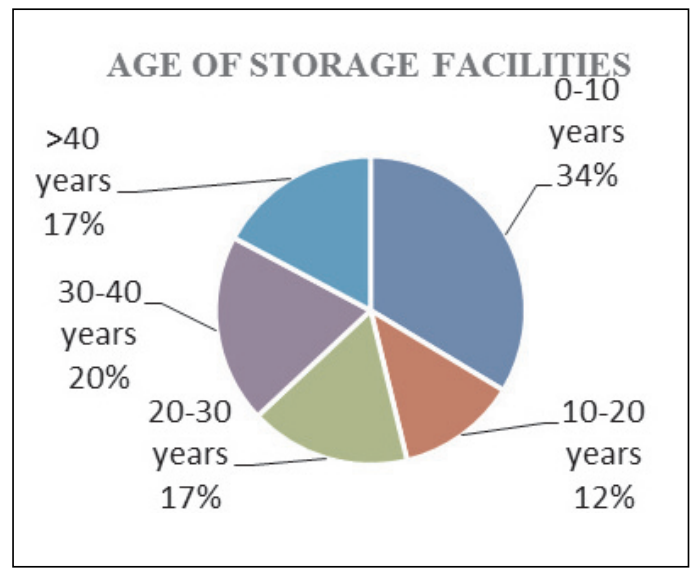

Fig. 17. Age of the storage facilities

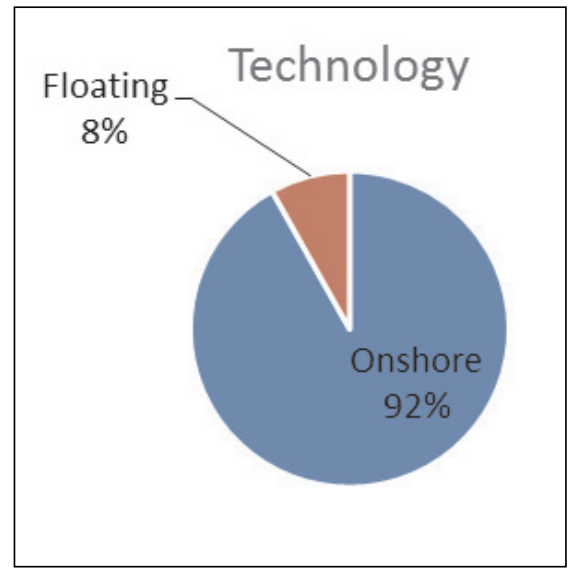

Fig. 18. Type of storage technology used (own research on the basis of [4])

\subsection{Gasification plants and storage tanks}

After the delivery of LNG to a terminal and regasification, natural gas can be used in a number of ways. Firstly, it can be applied in electricity production. If the distance between the terminal and the receiver is large, gas may be supplied to a gas network or distributed to smaller tanks by tanker trucks (Fig. 19). The costs of building a terminal include: storage section $45 \%$, gasification section $24 \%$, loading platform $11 \%$, usable floor area $16 \%$, social area $4 \%[9,18,28]$.

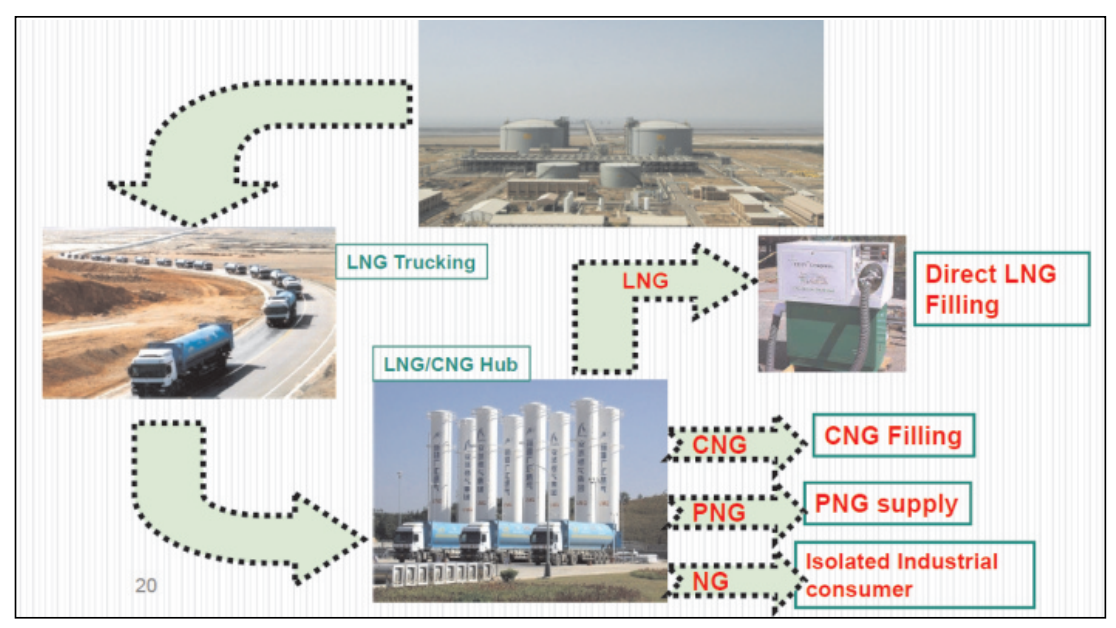

Fig. 19. LNG applications [28] 


\section{Tanks}

The terminal tank should have enough capacity to receive gas from an LNG carrier and to provide consumers with gas in case LNG deliveries suffer from delays. Three types of tanks can be distinguished [9, 29]:

1. Aboveground Storage Tank (AST). It consists of one insulated tank and is most frequently used worldwide.

2. Gas Tank. It consists of one internal concrete tank and one external tank.

3. Underground tank. The underground location is sometimes preferred for aesthetic and environmental reasons.

\section{Regasification technologies}

LNG, in order to be supplied to a grid, needs to be regasified. For that purpose, the following technologies [9] are used:

1. OVR (Open Rack Vaporizer) - is based on the use of seawater's heat (water is directed to heat exchangers in order to heat LNG).

2. SCV (Submerged Combustion Vaporizer) - is based on gas combustion in order to heat water in which $\mathrm{LNG}$ vaporizers are submerged.

The costs of this investment are lower as compared to ORV, but their exploitation costs are high.

3. STV (Shell and Tube Vaporizer) are used when an LNG terminal is connected to another facility, e.g. a power plant. Water is then heated by flowing through a horizontal shell.

\section{FORECASTING GAS PRICES WITH MULTIPLE REGRESSION ANALYSIS}

In order to forecast gas price, multiple regression of linear and power functions has been applied.

\subsection{Multiple regression - underlying assumptions}

The main focus of the present thesis is to determine the criterion variable which is LNG price on Henry Hub in the USA, by using multiple explanatory variables, such as: fuel prices, fuel consumption, yearly and monthly electricity consumption [30-32].

Underlying assumptions:

1. The model takes a linear form $Y=\beta x+\varepsilon$

where:

$\beta$ - parameter,

$\varepsilon-$ random component. 
2. Matrix is known and is not random.

3. Row of a matrix is $x=k$, where $k$-number of parameters

$T>k$

where:

$k$ - number of parameters,

$T$ - number of observations.

4. Expected value of random component equals 0 .

5. Variance of random component is constant and equals $\sigma^{2}$.

\section{Linear model: fitting and projection}

The linear model has the following generalized formula:

Form:

$$
Y=\beta_{0}+\beta_{1} \cdot X_{1}+\beta_{2} \cdot X_{2}+\ldots+\beta_{k} \cdot X_{k}+\varepsilon
$$

where:

$Y$ - dependent variable (whose value is explained by the model endogenous),

$X_{1}, \ldots, X_{k}-$ variables used to analyse $Y$,

$\beta_{0}, \beta_{1}, \beta_{2}, \ldots, \beta_{k}-$ parameters of the model (numbers),

$\varepsilon$ - random component.

In the linear model parameters that turned out essential were the prices of both imported and exported natural gas, as well as the prices of exported LNG (Tab. 2).

Table 2

Estimating parameters for the linear model

\begin{tabular}{|c|c|c|c|c|c|c|}
\hline & \multicolumn{6}{|c|}{$\begin{array}{c}\text { Summary of regression dependent variable: } \\
R=0.93556903 R^{2}=0.87528941, R^{2}=0.87113239 \\
F(5,150)=210,56 p<0.0000 \text { Standard error estimation: } 0.86091\end{array}$} \\
\hline & $b^{*}$ & $\begin{array}{c}\text { Standard } \\
\text { error from } b^{*}\end{array}$ & $b$ & $\begin{array}{c}\text { Standard } \\
\text { error from } b\end{array}$ & $t(150)$ & $p$ \\
\hline Free term & - & - & 0.44683 & 0.333037 & 1.3417 & 0.181728 \\
\hline Natural gas imports & 9.00592 & 0.572212 & 10.2854 & 0.653510 & 15.7388 & 0.0000 \\
\hline $\begin{array}{l}\text { Natural gas imports } \\
\text { by pipeline }\end{array}$ & -8.33894 & 0.648176 & -9.49734 & 0.738218 & -12.8652 & 0.0000 \\
\hline Natural gas export & -1.57666 & 0.446391 & -1.94037 & 0.549365 & -3.5320 & 0.0005 \\
\hline $\begin{array}{l}\text { Natural gas export } \\
\text { by pipeline }\end{array}$ & 1.70189 & 0.490268 & 1.95299 & 0.562604 & 3.4713 & 0.0006 \\
\hline LNG export & 0.15431 & 0.038143 & 0.0411 & 0.025734 & 4.0455 & 0.00008 \\
\hline
\end{tabular}


Model fitting and projection (Figs 20 and 21)

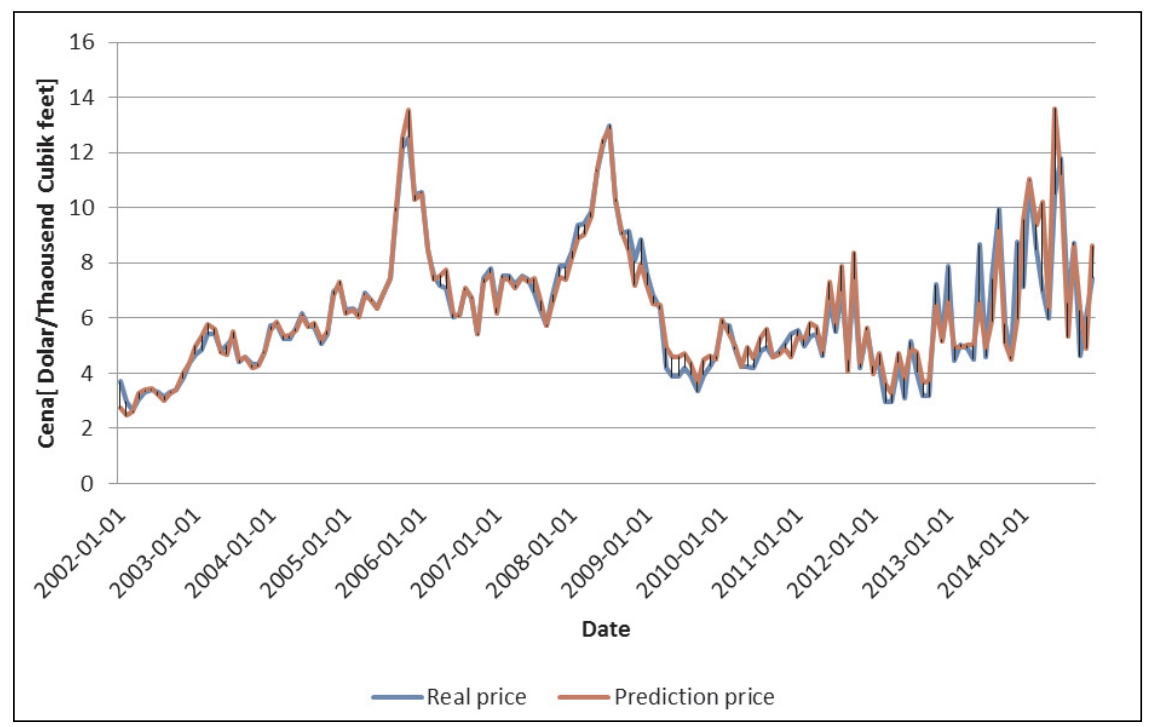

Fig. 20. Fitting the power model to actual prices

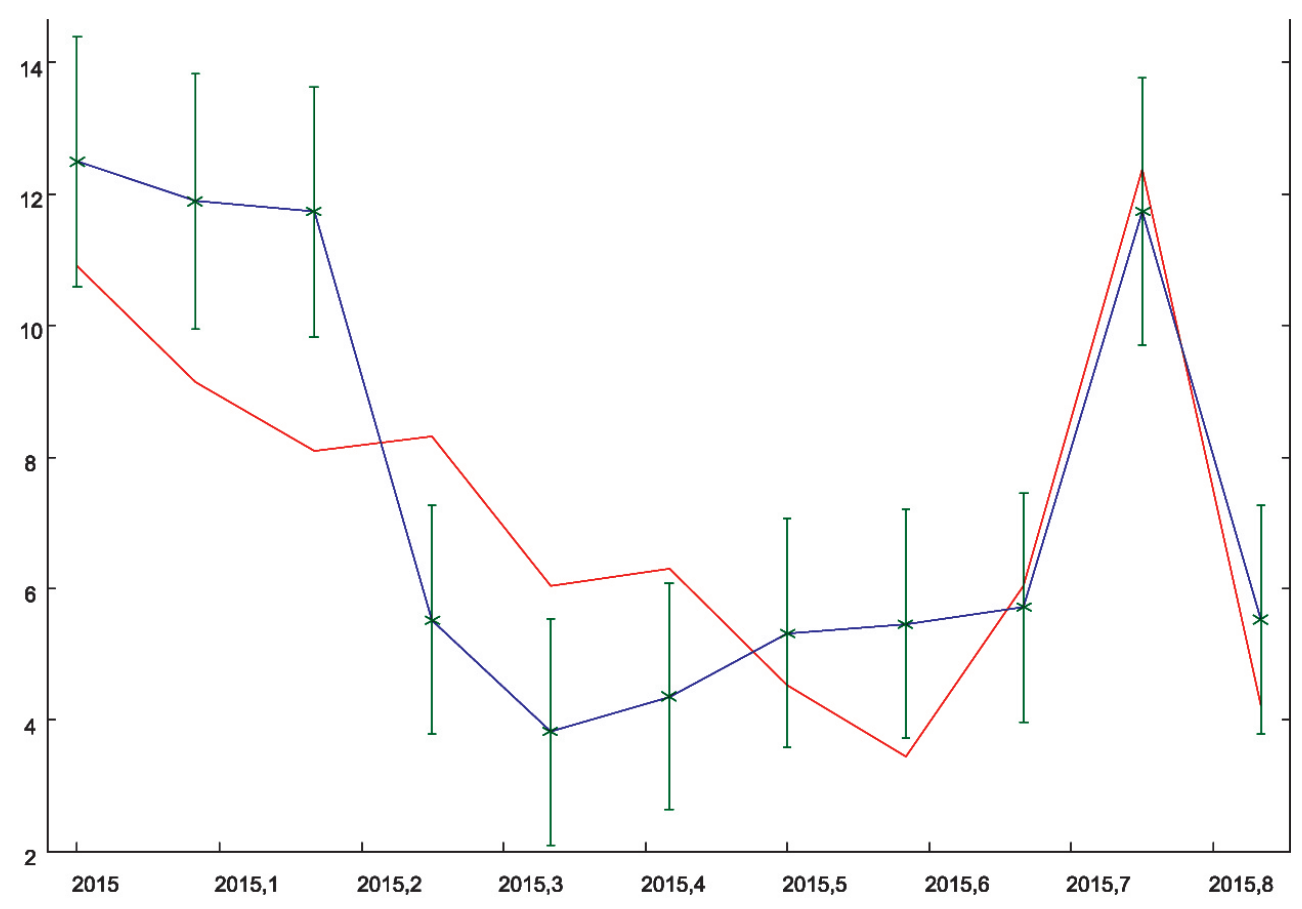

Fig. 21. Forecasting with the power model 
Assessment of estimated parameters:

- standard error of the estimate $=0.86091$,

- the average difference between actual and theoretical $Y$ values is 0.8609 , which is $13.72 \%$ of mean $Y$,

- $R^{2}=0.8752$ - total $Y$ variation has been explained in about $87.52 \%$ by the estimated model.

The model takes the following form:

$$
Y=0.44683+10.285 X_{1}-9.49734 X_{2}-1.94037 X_{3}+1.95299 X_{4}+0.0411 X_{5}
$$

\section{Power model: fitting and projection}

Power model assumes the following generalized formula:

$$
Y=\beta_{0} \cdot X_{1}^{\beta_{1}} \cdot X_{2}^{\beta_{2}} \cdot \ldots \cdot X_{k}^{\beta_{k}}
$$

where:

$$
\begin{aligned}
Y & - \text { dependent variable (whose value is explained by the model }- \\
& \text { endogenous) } \\
X_{1}, \ldots, X_{k}- & \text { variables used to analyse } Y, \\
\beta_{0}, \beta_{1}, \beta_{2}, \ldots, \beta_{k}- & \text { parameters of the model (numbers), } \\
\varepsilon- & \text { random component. }
\end{aligned}
$$

We reduce to the linear model by computing the logarithm $\ln (3)$ :

$$
\begin{gathered}
\ln (Y)=\ln \left(\beta_{0} \cdot X_{1}^{\beta_{1}} \cdot X_{2}^{\beta_{2}} \cdot \ldots \cdot X_{k}^{\beta_{k}}\right) \\
\ln (Y)=\ln \beta_{0}+\beta_{1} \ln X_{1}+\beta_{2} \ln X_{2}+\ldots+\beta_{k} \ln X_{k}
\end{gathered}
$$

In the linear model (3), parameters that turned out to be significant were the prices of both imported and exported natural gas, the prices of natural gas for industrial customers and the prices of exported LNG (Tab. 3).

Assessment of parameter estimation:

- standard error of the estimate $=0.10687$,

- the difference between computed logarithm $Y$ and theoretical values is 0.10687 , which is $5 \%$ of mean computed logarithm of $Y$,

- $R^{2}=0.91-$ about $91 \%$ of the total variance of the computed logarithm of $Y$ has been explained by the estimated model.

Model takes the form of:

$$
\begin{gathered}
\ln (Y)=-0.066+0.322 \ln X_{1}+6.3138 \ln X_{2}+6.3138 \ln X_{2}- \\
-5.4620 \ln X_{3}-1.5636 \ln X_{4}+1.2353 \ln X_{5}+0.1798 \ln X_{6}
\end{gathered}
$$


Table 3

Estimating parameters for the linear model

\begin{tabular}{|c|c|c|c|c|c|c|}
\hline & \multicolumn{6}{|c|}{$\begin{array}{c}\text { Summary of regression dependent variable: } \\
R=0.95687061 R^{2}=0.91560137, R^{2}=0.91220277 \\
F(6,150)=269,41 p<0.0000 \text { Standard error estimation: } 0.10687\end{array}$} \\
\hline & $b^{*}$ & $\begin{array}{c}\text { Standard } \\
\text { error from } b^{*}\end{array}$ & $b$ & $\begin{array}{c}\text { Standard } \\
\text { error from } b\end{array}$ & $t(150)$ & $p$ \\
\hline Free term & - & - & -0.0660 & 0.09946 & -0.663 & 0.50787 \\
\hline Industrial customer & 0.2704 & 0.10955 & 0.3220 & 0.13046 & 2.468 & 0.01469 \\
\hline Natural gas imports & 6.5950 & 0.39876 & 6.3138 & 0.38176 & 16.538 & 0.00000 \\
\hline $\begin{array}{l}\text { Natural gas imports } \\
\text { by pipeline }\end{array}$ & -5.8094 & 0.42804 & -5.4620 & 0.40245 & -13.572 & 0.00000 \\
\hline Natural gas export & -1.4615 & 0.32332 & -1.5636 & 0.34592 & -4.520 & 0.00001 \\
\hline $\begin{array}{l}\text { Natural gas export } \\
\text { by pipeline }\end{array}$ & 1.2433 & 0.33938 & 1.2353 & 0.33722 & 3.663 & 0.00034 \\
\hline LNG export & 0.2097 & 0.03267 & 0.1798 & 0.02801 & 6.417 & 0.00000 \\
\hline
\end{tabular}

Model fitting and projection (Figs 22 and 23)

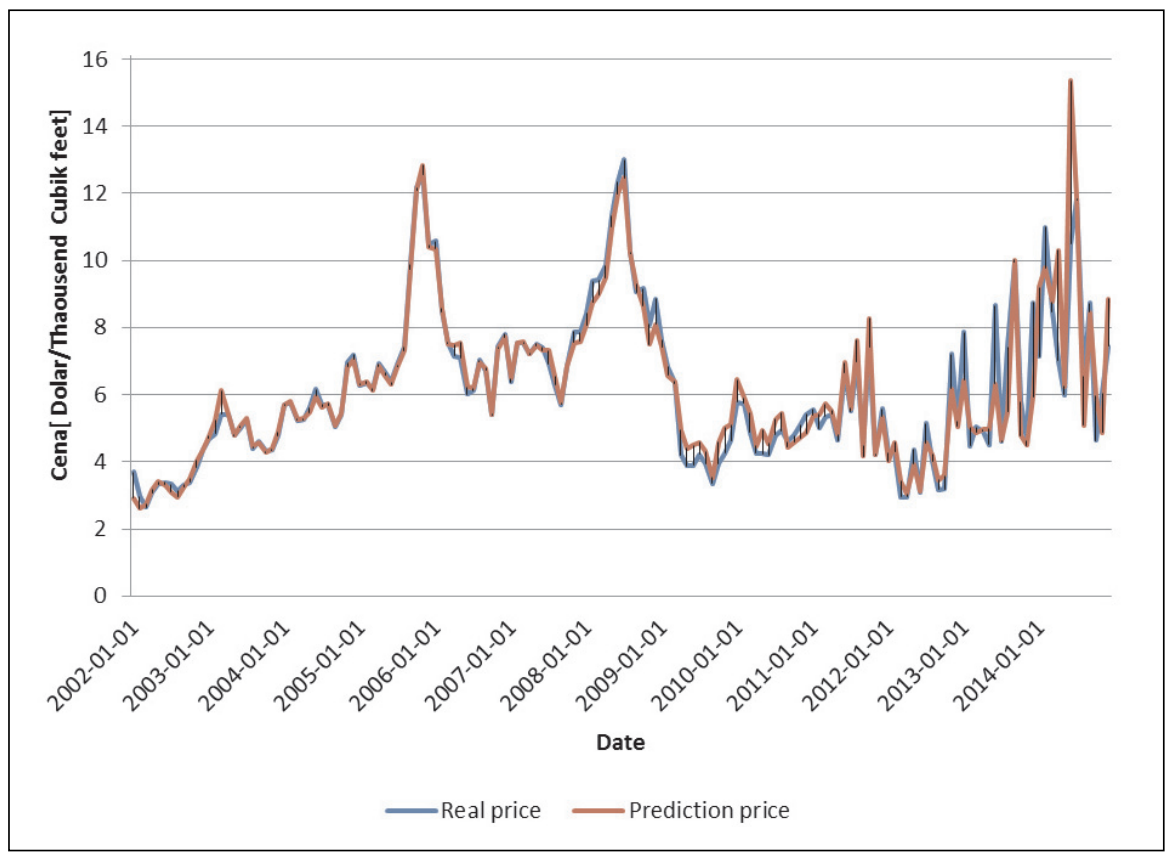

Fig. 22. Fitting the power model to actual prices 


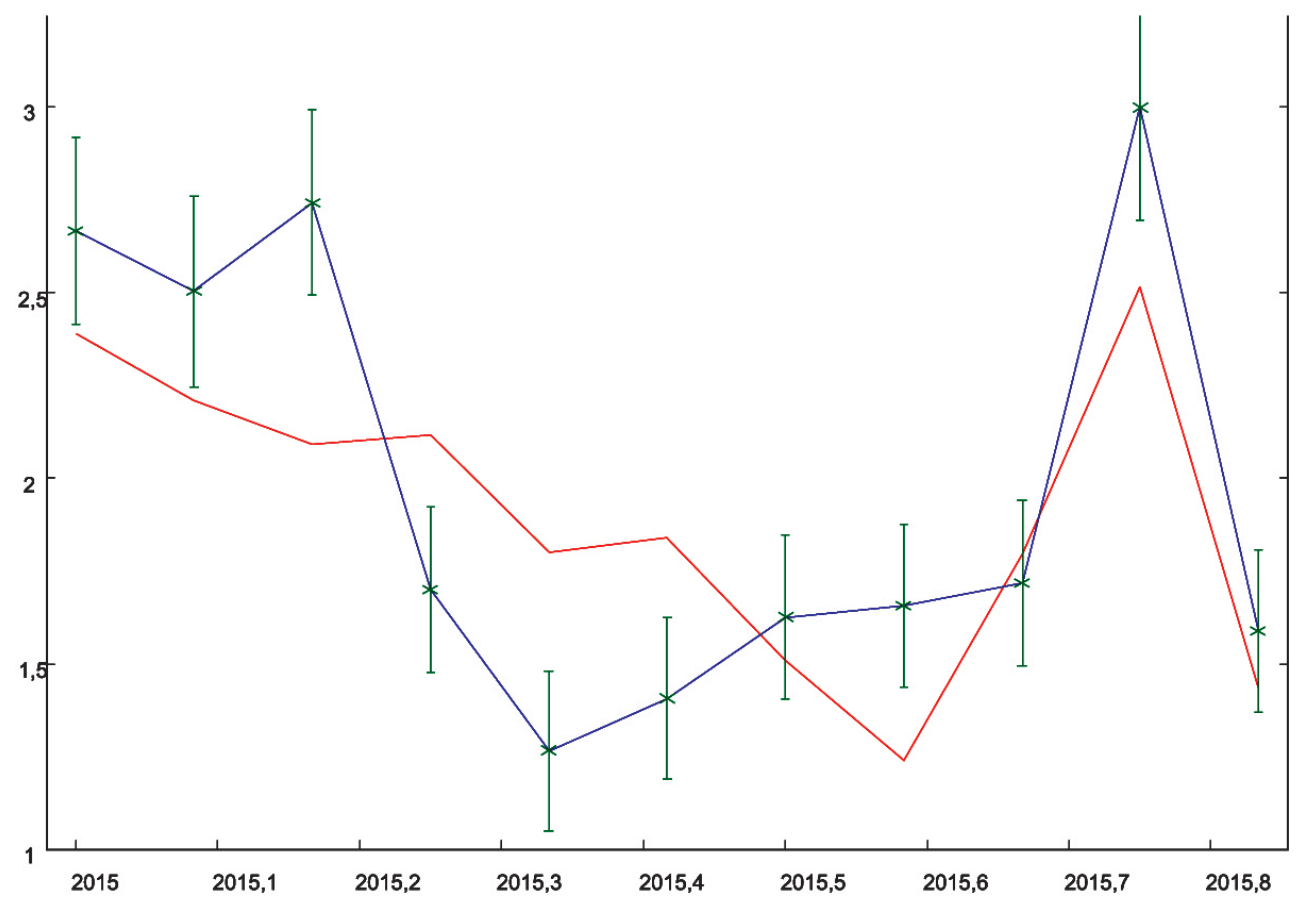

Fig. 23. Forecasting with the power model

\section{Comparison between models}

Model pairing was based on calculating the following projection values for both models: mean error (ME), root mean square error (RMSE), mean absolute percentage error (MAPE) (Tab. 4).

Table 4

Comparison of both methods

\begin{tabular}{|l|c|c|}
\hline \multicolumn{1}{|c|}{ Type of method } & Linear model & Power model \\
\hline Mean error (ME) & -0.22 & -0.08446 \\
\hline $\begin{array}{l}\text { Root mean square error } \\
\text { (RMSE) }\end{array}$ & 2.1023 & 0.39 \\
\hline $\begin{array}{l}\text { Mean absolute percentage } \\
\text { error (MAPE) }\end{array}$ & 28.08 & 18.59 \\
\hline
\end{tabular}

The Table 4 shows that the power model proved better for the purpose of projection. 


\section{CONCLUSIONS}

1. The projects undertaken in the effort of building new production facilities in countries such as the USA and Australia will cause a change in both countries' share of the world's production market in 2019. It should be expected that countries which so far have occupied high positions among the producers will attempt to maintain their position in the production market at the cost of lowering LNG price.

2. The majority of the world's LNG infrastructure, i.e. facilities used in production, transport vessels and terminals are less than 10 years old. This indicates that the LNG market is a growing one and substantial investments should be expected in the forthcoming years.

3. Maritime transport remains to be highly profitable, which is proved by the constant growth of the LNG carrier fleet. The solutions for the use of LNG in power plants and as car fuel are also appearing.

4. Thanks to multiple regression method, LNG price can be forecast with the use of explanatory variables. It appears that month, year or LNG consumption by particular industries are not factors influencing LNG price.

\section{REFERENCES}

[1] Pespektywy wykorzystania gazu ziemnego LNG w Polsce. Wiadomości Naftowe i Gazownicze, No. 11, 2012.

[2] http://lng.edu.pl/wpcontent/uploads/lng/attachments/DZIENNIK\%20GAZETA \%20PRAWNA_odc_5_LNG\%20jeden\%20gaz\%20-\%20wiele\%20zastosowa\% C5\%84.pdf (access: 1-3.03.2016).

[3] http://www.polskielng.pl/lng/ ( access: 1-3.03.2016).

[4] IGU World LNG Report - 2015 Edition, http://www.igu.org/publications (access: 1-3.03.2016).

[5] Pettersen J.: LNG Plant Overview. Murmańsk 2012.

[6] Rivera V.: Evaluation of LNG Technologies. April 302008.

[7] https://www.aga.org/ (access: 1-3.03.2016).

[8] Pillarella M. et al: The C3MR liquefaction cycle: versatility for a fast growing, ever changing LNG industry. Air Products and Chemicals, Inc., Allentown, Pennsylvania. Paper PS2-5.

[9] http://www.unece.org/fileadmin/DAM/energy/se/pdfs/wpgas/session/1st_Session_ Group_Experts_on_gas/0_-_LNG_Study_Introduction_and_Overview.pdf (access: 1-3.03.2016).

[10] Martin P.-Y.: Natural gas liquefaction processes comparison. Axens (France) www.axens.fr IFP (France).

[11] Pereira C.: Thermodynamic Analysis for Liquefaction of Natural Gas Using the C3-MR Refrigeration Process. International Journal of Chemical Engineering and Applications, vol. 5, No. 1, February 2014. 
[12] Spilsbury C. et al.: Evolution of Liquefaction Technology for today's LNG business. Air Products and Chemicals", Inc., 7201 Hamilton Blvd, Allentown, Pennsylvania, USA 18195-1501.

[13] Catillo L. et al.: Technology selection for liquefied natural gas (LNG) on bas load plant. "Gas technical Management", XIX International Gas Convention, Caracas 2010.

[14] Bukowski J.D.: Natural gas liquefaction technology for floating LNG facilities; LNG Major Account Manager. Air Products and Chemicals, Inc. Allentown, PA, USA 18195-1501.

[15] Andress D.L.: The Phillips optimized cascade LNG process a quarter century of improvement. Philips Petroleum Company, 1996.

[16] Russell H.: LNG liquefaction process selection: alternative refrigerants to reduce footprint and cost. ExxonMobil Upstream Research Company.

[17] http://member.zeusintel.com/lng/Ships/ (access: 1-3.03.2016).

[18] Foss M.M.: Introduction to LNG. Houston, 2007.

[19] http://www.arcticgas.gov/lng-market-overview-looks-supply-and-demand $\quad$ 12.04.2015.

[20] http://www.gastechnology.org (access: 1-3.03.2016).

[21] http://www.giignl.org, LNG Information Paper No. 2 (access: 1-3.03.2016).

[22] US. Department of Energy, Office of Fossil Energy, www.fossil.energy.gov (access: 1-3.03.2016).

[23] Neil Chapman, BP; image courtesy of BP.

[24] Liquefied Natural Gas (LNG), Receiving Terminal and Associated Facilities May 2005, Environmental Resources Management.

[25] Harper Ian: Future Development Options for LNG Marine Transportation, paper presented at the American Institute of Chemical Engineers. Spring National Meeting in New Orleans,March 10-14, 2002. Also see www.coltoncompany.com. (access: 1-3.03.2016).

[26] http://www.wearethepractitioners.com/library/the-practitioner/2014/02/25/natural-gas-ships (access: 1-3.03.2016).

[27] The Magazine for Customers and Business Partners, edition no. 022007.

[28] Mishra S.: Petrtech LNG Program. Small Scale LNG Plant-Roads/Costal Movements, 2012.

[29] http://www.giignl.org, LNG Information Paper, No. 5 (access: 1-3.03.2016).

[30] http://www.eia.gov/ (access: 1-3.03.2016).

[31] Rabiel M.: Statystyka z programem Statistica. Helion, 2012.

[32] Stanisz A.: Przystęny kurs statystyki z zastosowaniem programu Statistica na przykładach z medycyny, Tom II. StatSoft, Kraków 2007.

[33] Goryl A.: Wprowadzenie do ekonometrii w przykładach i zadaniach. PWN, 2000.

[34] http://euanmearns.com/lng-heading-east/ (access: 12.04.2016). 